\title{
Stainless Steel Electrodeposited with Zinc is not Good for Storing Thiourea Solution
}

\author{
S. Rajendran, ${ }^{1, *}$ V. Agnes Brigita, ${ }^{2}$ J. Manivannan, ${ }^{3}$ J. Jeyasundari ${ }^{4}$ \\ ${ }^{1}$ Corrosion Research Centre, Post Graduate and Research, Department of Chemistry, G.T.N \\ Arts College, Dindigul -624005, Tamil Nadu, India. \\ ${ }^{2}$ RVS College of Education, RVS Nagar, Dindigul - 624005, Tamil Nadu, India. \\ ${ }^{3}$ Department of Chemistry, Chettinad College of Engineering and Technology, Karur-639114, \\ Tamil Nadu, India. \\ ${ }^{4}$ Department of Chemistry, SVN College, Madurai, India
}

Received 14 February 2009; accepted 24 September 2009

\begin{abstract}
The use of stainless steel 304(SS) tanks to deposit thiourea in industry has been evaluated by studying the corrosion behaviour in $1 \%$ thiourea solution, before and after zinc plating. Weight loss method, $1 \%$ copper sulphate test, polarization study and AC impedance spectra have been used. The corrosion resistance of SS decreased when zinc was used for electrodeposition. Hence SS vessels electroplated with zinc should not be used to store thiourea solution, in industry.
\end{abstract}

Keywords: stainless steel, zinc plating, corrosion, thiourea, case study.

\section{Introduction}

Tin-zinc alloy coatings have good corrosion resistance, good frictional properties and ductility, and good solder ability. In view of their good properties, they have been proposed as substitutes for other industrial coatings, such as those of toxic cadmium and allergenic nickel [1,2]. Tin-zinc electro deposition has been investigated using different bath systems [3-11], at different $\mathrm{pH}$ values and using different complexing agents and additives, in order to replace the contaminant cyanide baths used in industrial processes for tin-zinc alloy plating [12]. In some of these studies $[3,6,9]$ it has been reported that alloy coatings with $20-30 \% \mathrm{Zn}$ by weight have better mechanical and corrosion protection properties. Others of these studies reported the conditions to obtain the eutectic Sn-Zn alloy by electro deposition [10,11]. The electro deposition of tin-zinc alloys with $20-30 \% \mathrm{Zn}$ from sulphate-tartrate baths at $\mathrm{pH} 4$ and 5 has been studied. The anodic stripping

\footnotetext{
* Corresponding author. E-mail address: srmjoany@ sify.com.
} 
analysis of the deposits was correlated with their morphology, composition and phase structure, both on vitreous carbon and on copper electrodes. The use of tartrate anion as a complexing agent allows deposits to be obtained with a uniform composition and morphology under stirred conditions during the electro deposition process [13].

Corrosion behaviour of zinc plated stainless steel fasteners [14] and zinc plated stainless steel bolts [15] has been investigated. Stainless steel 304 (SS) is used to store thiourea solution in industries. It will be interesting to know if SS electrodeposited with $\mathrm{Zn}$ can be used in thiourea industry. If this vessel is not good even for $1 \%$ thiourea solution definitely higher concentration will have adverse effect.

The present work is a case study of small scale electroplating industry. It is undertaken

(i) to electroplate zinc on stainless steel 304 surface, in the real situation of an electroplating unit;

(ii) and to study the corrosion resistance behaviour of the above electroplated surface:

(a) introducing it in an aqueous solution containing $1 \%$ thiourea;

(b) putting a drop of $\mathrm{CuSO}_{4}$ solution on the metal surface; and

(c) and analyzing the polarization and AC impedance spectroscopy.

\section{Experimental}

\section{Preparation of the specimen}

Stainless steel 304 noted SS (with the chemical composition: $10 \% \mathrm{Cr}, 8 \% \mathrm{Ni}$, $0.80 \% \mathrm{Mn}, 0.044 \% \mathrm{C}, 0.0025 \% \mathrm{P}, 0.0015 \% \mathrm{~S}$, and the rest iron) specimens with the dimensions $1.0 \times 4.0 \times 0.2 \mathrm{~cm}$ were used in the present study for electroplating and the investigation of the corrosion resistivity of metal surface.

Carbon steel specimens $(0.026 \% \mathrm{~S}, 0.06 \% \mathrm{P}, 0.4 \% \mathrm{Mn}, 0.1 \% \mathrm{C}$ and rest iron) with the dimensions $1.0 \times 4.0 \times 0.2 \mathrm{~cm}$ were used in the present study.

Electroplating was done in a real situation in a small scale electroplating unit.

\section{Electroplating}

The process of electroplating of the stainless steel specimen involves the following steps:

The SS specimens were pickled with conc. $\mathrm{HCl}$ and washed with distilled water followed by drying in the air. The dried specimens were polished with nice emery and degreased with cleaning powder containing soda, chalk and fine emery powder. After drying, the metal specimens were immersed into the bath solution.

The bath solution consists of $\mathrm{ZnCl}_{2}(100 \mathrm{~g} / \mathrm{L}), \mathrm{KCl}(225 \mathrm{~g} / \mathrm{L})$ and $\mathrm{H}_{3} \mathrm{BO}_{4}(40$ $\mathrm{g} / \mathrm{L})$. Pure zinc plate was used as anode and SS specimen was used as cathode. Direct current passed for 5 minutes, at room temperature, without agitating the bath solution. After electroplating, the specimens were washed with water and dried in the air. 


\section{Measurement of corrosion resistance of the electroplated metal surface}

The following studies were used to evaluate the corrosion protective property nature of the film formed on the stainless steel surface after electroplating.

\section{Immersion in $1 \%$ thiourea solution}

The metal specimens in triplicate were immersed in $100 \mathrm{~mL}$ of an aqueous solution containing $1 \%$ thiourea for one day. After this, the corrosion product, if formed, was cleaned with Clarke's solution [16]. The corrosion rate (CR) was calculated using the equation.

$$
\mathrm{CR}=\frac{\text { Weight loss in } \mathrm{mg}}{\text { Surface area in } \mathrm{dm}^{2} \times \text { immersion period in days }} \mathrm{mdd}
$$

\section{Action of $1 \%$ copper sulphate solution}

One drop of $1 \%$ copper sulphate solution was placed on the surface of the metal. The time taken for the formation of a red solution due to the formation of $\mathrm{Cu}$ was determined. During of the corrosion process the colour is changing because of the electrons transfer [17-18].

$$
\underset{\text { blue }}{\mathrm{Fe}+\mathrm{Cu}^{2+}} \rightarrow \mathrm{Fe}^{2+}+\underset{\text { red }}{\mathrm{Cu}}
$$

Copper has a reddish, orange coloured, or brownish colour, because of a thin layer of tarnish (including oxides) gradually formed on its surface when gases (especially oxygen) in the air react with it [18].

Hence, the time required for the formation of a red solution is an indication of an electron transfer rate (corrosion process) from the iron to the $\mathrm{Cu}^{2+}$ ion on the metal surface.

\section{Potentiodynamic polarization}

Polarization studies were carried out in a CHI - Electrochemical workstation with impedance, Model 660A. A three-electrode cell assembly was used. The working electrode was CS, stainless steel or stainless steel electroplated with zinc. A saturated calomel electrode (SCE) was the reference electrode and platinum was the counter electrode. From the polarization study, corrosion parameters such as corrosion potential $\left(\mathrm{E}_{\text {corr }}\right)$, corrosion current $\left(\mathrm{I}_{\text {corr }}\right)$ and Tafel slopes (anodic $=\mathrm{b}_{a}$ and cathodic $=\mathrm{b}_{c}$ ) were calculated.

\section{AC impedance spectra}

The equipment was used for polarization study and to record AC impedance spectra also. The cell setup was also the same. The real part ( $\left.Z^{\prime}\right)$ and imaginary part (Z") of the cell impedance were measured in ohms at various frequencies. Values of the charge transfer resistance $\left(\mathrm{R}_{t}\right)$ and the double layer capacitance $\left(\mathrm{C}_{d l}\right)$ were calculated. 


\section{Cyclic voltammetry}

Cyclic voltammograms were recorded with the cell set up used for polarization study. The scan rate was $0.1 \mathrm{~V} / \mathrm{s}$.

\section{Results and discussion}

\section{Analysis of results of weight loss method}

In the present study the corrosion behaviour of carbon steel (CS) is taken as a reference. Corrosion rates of carbon steel (CS) (without any coating), stainless steel 304(SS) sample, and SS electroplated with zinc $(\mathrm{SS}+\mathrm{Zn})$ were immersed in an aqueous solution containing $1 \%$ thiourea, obtained by weight loss method, and given in Table 1.

Table 1. Corrosion rates (CR) of carbon steel (CS), stainless steel (SS) and stainless steel electroplated with zinc ( $\mathrm{SS}+\mathrm{Zn}$ ) immersed in an aqueous solution containing $1 \%$ thiourea, obtained by weight loss method.

\begin{tabular}{|l|c|c|}
\hline \multicolumn{1}{|c|}{ Sample } & Thiourea $\%$ & CR mdd \\
\hline CS & 1 & 0.91 \\
\hline SS & 1 & Nil \\
\hline SS + Zn & 1 & 8.18 \\
\hline
\end{tabular}

The corrosion rate of CS is $0.91 \mathrm{mdd}$. It is observed that when zinc plating was done on $\mathrm{SS}$ for five minutes $(\mathrm{SS}+\mathrm{Zn})$, the corrosion rate $(\mathrm{CR})$ increased from 0.00 to 8.18 mdd (Fig. 1).

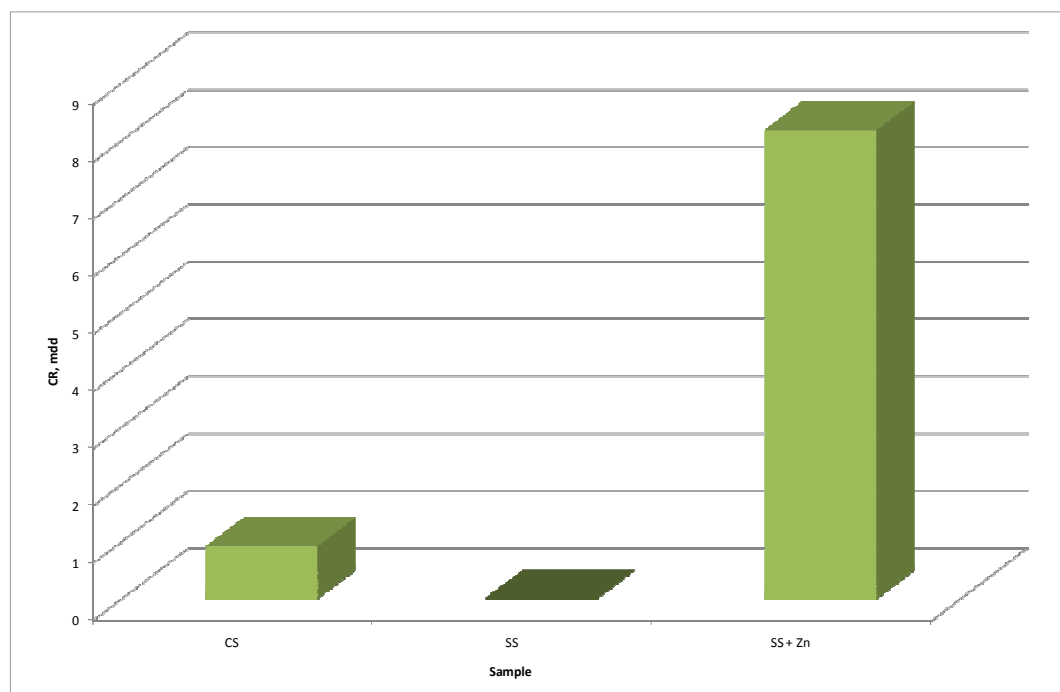

Figure 1. Corrosion rate of carbon steel (CS), stainless steel (SS) samples, before and after electroplating with zinc immersed in an aqueous solution containing $1 \%$ thiourea, obtained by weight loss method.

During the electroplating process, zinc was deposited on the stainless steel surface. When zinc plated stainless steel was immersed in an aqueous solution 
containing $1 \%$ thiourea, the zinc film deposited on SS goes into solution. SS becomes cathode and zinc becomes anode [19]. Hence, zinc undergoes corrosion and the corrosion rate increased from $0.00 \mathrm{mdd}$ to $8.18 \mathrm{mdd}\left(\mathrm{mg} / \mathrm{dm}^{2}\right.$ day).

\section{Action of 1\% copper sulphate solution on the metal surface}

Time for the appearance of reddish brown solution, when a drop of $1 \%$ copper sulphate solution was placed on the metal surface, before and after electroplating, is given in Table 2 .

Table 2. Time from the appearance of reddish brown solution when one drop of $1 \%$ copper sulphate solution was placed on the metal surface, before and after electroplating.

\begin{tabular}{|l|l|c|}
\hline Sample & \multicolumn{2}{|c|}{ Time taken for the appearance of red colour, (s) } \\
\hline CS & \multicolumn{1}{|c|}{ Just appearance } & \multicolumn{1}{c|}{ Complete appearance } \\
\hline SS & $\begin{array}{l}\text { No appearance of reddish brown colour even after } \\
\text { 2400 seconds }\end{array}$ \\
\hline SS + Zn & $\begin{array}{l}\text { No appearance of reddish brown colour even after } \\
\text { 2400 seconds }\end{array}$ \\
\hline
\end{tabular}

When a drop of $1 \%$ copper sulphate was placed on the polished CS surface, a red solution started appearing at $65^{\text {th }}$ second. The colour appearance was completed at $155^{\text {th }}$ second. In the case of uncoated stainless steel (SS) surface and zinc plated stainless steel $(\mathrm{SS}+\mathrm{Zn})$ surface, the reddish brown colour did not appear even after 2400 seconds. This indicates that in uncoated stainless steel there is no transfer of electron from $\mathrm{Fe}$ to $\mathrm{Cu}^{2+}$. In the case of zinc coated stainless steel $(\mathrm{SS}+\mathrm{Zn})$ there is a protective film formed on the metal surface. This protective film prevents the transfer of electron from $\mathrm{Fe}$ to $\mathrm{Cu}^{2+}$, but in the case of polished carbon steel, the formation of reddish brown solution is due to the conversion of blue $\mathrm{Cu}^{2+}$ ion into reddish $\mathrm{Cu}$. This process takes place by the electrons supplied with Fe, when it undergoes corrosion (eq. 2).

\section{Analysis of potentiodynamic polarization study}

The polarization curves of stainless steel (SS) samples, before and after electroplating, immersed in an aqueous solution containing $1 \%$ thiourea, are shown in Fig. 2. The corrosion parameters are given in Table 3.

When CS is immersed in $1 \%$ thiourea solution, the corrosion potential is -692 $\mathrm{mV} / \mathrm{dec}$. The linear polarization resistance (LPR) value is low $\left(7.887 \mathrm{x} 10^{2} \mathrm{ohm}\right.$ $\left.\mathrm{cm}^{2}\right)$. The corrosion current is high $\left(6.909 \times 10^{-5} \mathrm{~A} / \mathrm{cm}^{2}\right)$. 
Table 3. Corrosion parameters of metal specimens, immersed in an aqueous solution containing $1 \%$ thiourea.

\begin{tabular}{|c|c|c|c|c|c|}
\hline Sample & $\begin{array}{c}\mathrm{E}_{\text {corr }} \\
\mathrm{mV} \text { vs. SCE }\end{array}$ & $\begin{array}{c}\mathrm{b}_{c} \\
\mathrm{mV} / \mathrm{dec}\end{array}$ & $\begin{array}{c}\mathrm{b}_{a} \\
\mathrm{mV} / \mathrm{dec}\end{array}$ & $\begin{array}{c}\text { LPR } \\
\text { ohm cm }\end{array}$ & $\begin{array}{c}\mathrm{I}_{\text {corr }} \\
\mathrm{A} / \mathrm{cm}^{2}\end{array}$ \\
\hline $\mathrm{CS}$ & -692 & 561 & 161 & $7.887 \times 10^{2}$ & $6.909 \times 10^{-5}$ \\
\hline SS & 678 & 345 & 93 & $1.671 \times 10^{5}$ & $1.906 \times 10^{-7}$ \\
\hline $\mathrm{SS}+\mathrm{Zn}$ & -1015 & 253 & 176 & $1.441 \times 10^{4}$ & $3.206 \times 10^{-6}$ \\
\hline
\end{tabular}

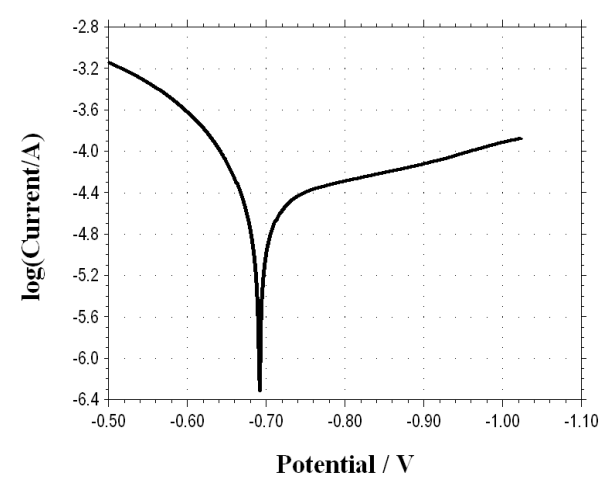

a)

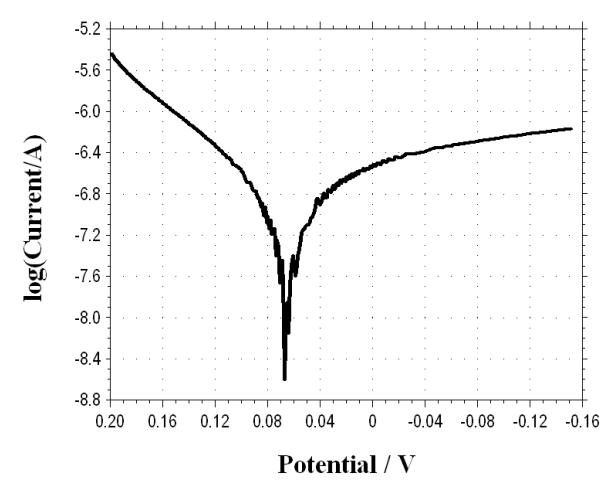

b)

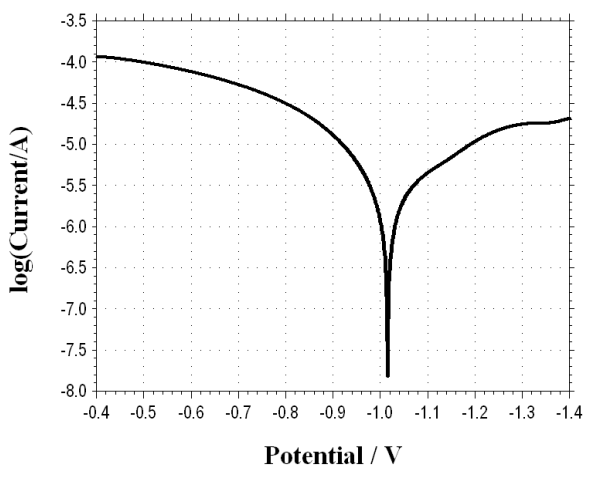

c)

Figure 2. Polarization curve of metal specimen immersed in an aqueous solution containing 1\% thiourea: (a) carbon steel, (b) stainless steel, and (c) stainless steel electroplated with zinc.

The corrosion potential $\left(\mathrm{E}_{\text {corr }}\right)$ of uncoated stainless steel is $678 \mathrm{mV}$ vs. SCE. The linear polarized resistance (LPR) value is $1.671 \times 10^{5} \mathrm{ohm} \mathrm{cm}^{2}$ and the corrosion current $\left(\mathrm{I}_{\text {corr }}\right)$ is $1.906 \times 10^{-7} \mathrm{~A} / \mathrm{cm}^{2}$. When stainless steel $(\mathrm{SS})$ is coated with zinc $(\mathrm{SS}+\mathrm{Zn})$, the corrosion potential shifts to the cathodic side $(-1015 \mathrm{mV}$ vs. SCE). This is due to the deposition of $\mathrm{Zn}$ on SS surface. The LPR value decreases to $1.411 \times 10^{4} \mathrm{ohm} \mathrm{cm}^{2}$ and $\mathrm{I}_{\text {corr }}$ values increase to $3.206 \times 10^{-6} \mathrm{~A} / \mathrm{cm}^{2}$. These observations suggest that the corrosion protecting efficiency decreases when SS is electroplated with $\mathrm{Zn}$ and the corrosion rate increases. This suggests that zinc film coated on SS is easily broken when immersed in $1 \%$ thiourea solution. This enhances the corrosion rate of iron in SS, as thiourea solution enters into the pores created by the breaking of zinc film coated on SS surface. This process seems to be dangerous. Hence SS containers coated with zinc should not be used 
to preserve thiourea solution in thiourea industry. The corrosion resistance of SS is better than carbon steel, as revealed by higher LPR value and lower corrosion current for SS compared with carbon steel.

\section{Analysis of AC impedance spectra}

$\mathrm{AC}$ impedance spectra of various metal specimens immersed in $1 \%$ thiourea solution are shown in Fig. 3.
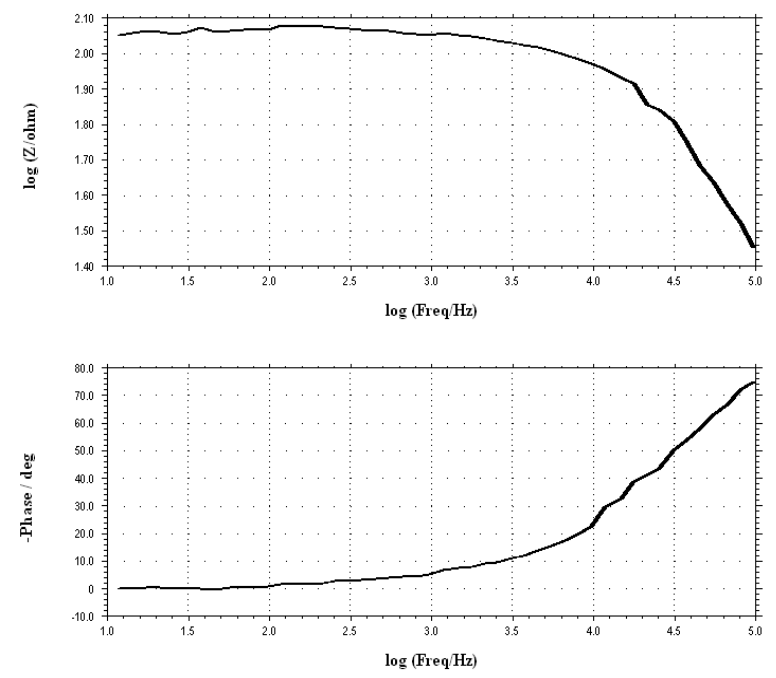

Figure 3a. AC impedance spectra (Bode plots) of metal specimens immersed in an aqueous solution containing $1 \%$ thiourea: (a) carbon steel.
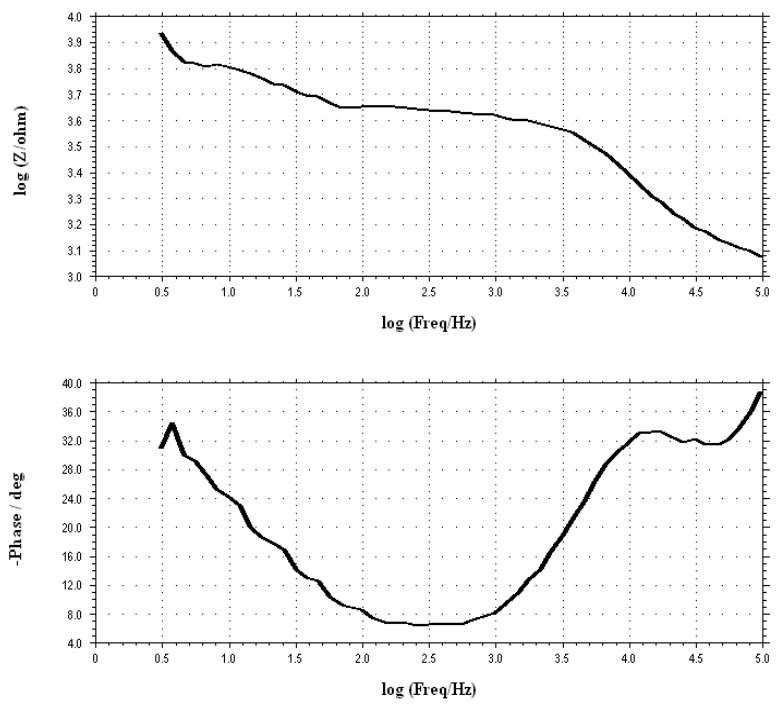

Figure 3b. AC impedance spectra (Bode plots) of metal specimens immersed in an aqueous solution containing $1 \%$ thiourea: (b) stainless steel. 

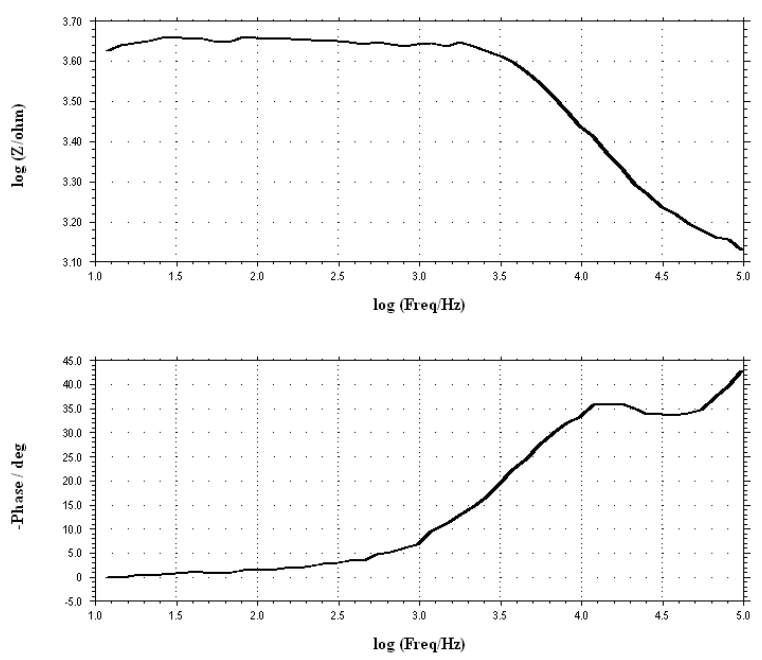

Figure 3c. AC impedance spectra (Bode plots) of metal specimens immersed in an aqueous solution containing $1 \%$ thiourea: (c) SS $+\mathrm{Zn}$.

It is observed from Bode plots (Fig. 3 a,b,c) and Table 4 that the real impedance value $[\log (\mathrm{Z} / \mathrm{ohm})]$ for CS is low (2.06). The real impedance value $\log (\mathrm{Z} / \mathrm{ohm})$ for uncoated stainless steel is 3.94. For zinc plated stainless steel $(\mathrm{SS}+\mathrm{Zn})$ this value slightly decreases to 3.63. This suggests that the corrosion protecting efficiency decreases when stainless steel (SS) is electroplated with zinc. So, the corrosion rate increases, when SS is electroplated with zinc. This is in agreement with the result obtained from polarization study. It is also observed that the real impedance value of SS (3.94) is higher than that of carbon steel (2.06). These observations suggest that $\mathrm{SS}$ is more corrosion resistant than CS and $\mathrm{SS}+\mathrm{Zn}$, in $1 \%$ thiourea solution.

Table 4. AC impedance parameters of metal specimens, immersed in an aqueous solution containing $1 \%$ thiourea.

\begin{tabular}{|l|c|}
\hline \multicolumn{1}{|c|}{ Sample } & Real impedance $\log (\mathrm{Z} / \mathrm{ohm})$ \\
\hline $\mathrm{CS}$ & 2.06 \\
\hline $\mathrm{SS}$ & 3.94 \\
\hline $\mathrm{SS}+\mathrm{Zn}$ & 3.63 \\
\hline
\end{tabular}

\section{Analysis of cyclic voltammograms}

The cyclic voltammograms of metal specimens immersed in an aqueous solution containing 1\% thiourea before and after electroplating are shown in Fig. 4.

It is found that the cyclic voltammograms do not show any characteristic peaks or redox couples.

It is observed from Fig. 4b that, when $\mathrm{SS}$ is immersed in $1 \%$ thiourea solution, SS metal surface is quite stable towards corrosion in the potential range +0.2 to - 
$0.4 \mathrm{~V}$ during forward scan. The current value remains constant. During reverse scan, it is stable in the potential range $+0.4 \mathrm{~V}$ to $-0.45 \mathrm{~V}$.

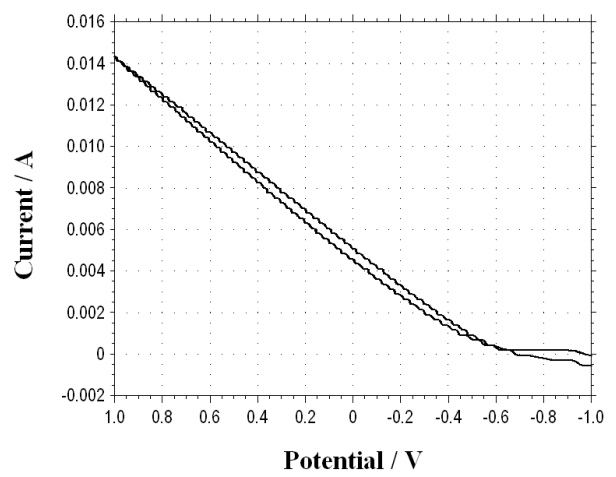

a)

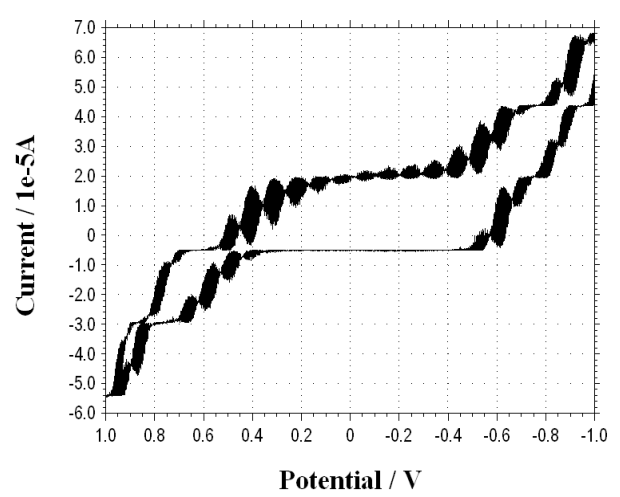

b)

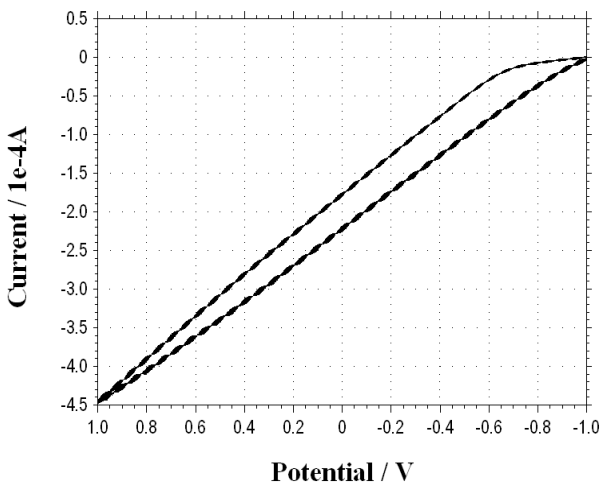

c)

Figure 4. Cyclic voltammograms of metal specimens immersed in an aqueous solution containing 1\% thiourea: (a) carbon steel, (b) stainless steel and (c) SS + Zn.

\section{Conclusions}

Zinc was electro deposited on stainless steel 304 surface using a bath containing zinc chloride, potassium chloride and boric acid. The corrosion rates of metal specimens such as carbon steel, stainless steel 304 (SS), and SS electroplated with $\mathrm{Zn}(\mathrm{SS}+\mathrm{Zn})$ were evaluated by weight loss method, copper sulphate test method, polarization and AC impedance studies. The present study leads to the following conclusions:

- when carbon steel is immersed in $1 \%$ aqueous thiourea solution, it undergoes corrosion;

- when uncoated stainless steel was immersed in an aqueous solution containing $1 \%$ thiourea, no corrosion of metal was observed.

Analytical test

- When $1 \%$ copper sulphate solution was placed on the uncoated stainless steel surface and zinc deposited, in both cases the red precipitate of copper did not appear even after 2400 seconds.

- Polarisation study leads to the conclusion that when stainless steel is electroplated with zinc, the metal surface becomes less corrosion resistant. 
- Analysis of AC impedance spectra reveals that the corrosion protecting efficiency decreases when SS is coated with zinc.

- When SS 304 is electrodeposited with zinc, the corrosion rate increases.

- Stainless steel vessel electroplated with zinc should not be used to preserve thiourea solution in thiourea industry.

\section{Acknowledgement}

The authors are thankful to their managements, St. Joseph's Research and Community Development Trust, Dindigul-3 and University Grants Commission, India, for their help and encouragement.

\section{References}

1. D.A. Schario, M.L. Klingenberg, E.W. Brooman, Abstracts of the 190th Meeting of the Electrochem. Soc., Vol. 96-2, No.309, The Electrochem. Soc., Pennington, NJ, 1996, p. 398.

2. M. Pushpavanaman, Bull. Electrochem. 16 (2000) 559.

3. O.A. Ashiru, J. Shiroko, Appl. Surf. Science 103 (1996) 159.

4. V.S. Vasantha, M. Pushpavanam, P. Kamaraj, V.S. Muralidharan, Trans. IMF 74 (1996) 28.

5. St. Vitkova, V. Ivanova, G. Raichevsky, Surf. Coat. Tech. 82 (1996) 226.

6. M. An, Y. Zhang, J. Zhang, Z. Yang, Z. Tu, Plating Surf. Finishing 86 (1999) 130.

7. L. Szira 'ki, A'. Czira'ki, Z. Ve'rtesy, L. Kiss, V. Ivanova, G. Raichevski, S. Vitkova, Ts. Marinova, J. Appl. Electrochem. 29 (1999) 927.

8. S.M. Abdel-Wahab, E. Mohamed, S.M. Rashwan, Metall. 54 (2000) 268.

9. K. Wang, H.W. Pickering, K.G. Weill, Electrochim. Acta 46 (2001) 3835.

10. E. Guaus, J. Torrent, J. Electroanal. Chem. 549 (2003) 25.

11. K. Wang-Lung, Li-Min Sun, J. Mater. Res. 18 (2003) 2203.

12. A. Brenner, Electrodeposition of Alloys: Principles and Practice, Vol. II, Academic Press, New York, 1963, p. 30.

13. E. Guaus, J. Torrent-Burgués, Journal of Electroanalytical Chemistry, 575 (2005) 301

14. http://www.finishing.com/160/63.shtml

15. http://www.finishing.com/380/35.shtml

16. G. Wranglen, Introduction to Corrosion and Protection of Metals, Chapman and Hall, London, 1985, p.236.

17. Clyde E. Williams and E. Anderson, The Journal of Industrial and Engineering Chemistry, Nov. 1922, p.1057.

18. http://en.wikipedia.org/wiki/copper

19. M.G. Fontana, Corrosion Engineering, Tata McGraw-Hill Publishing Company Ltd., New Delhi, 2006, p.43. 